\title{
The Effect of Leaders' Emotional Intelligence on Employees' Organization Commitment in Malaysia
}

\author{
Choi Sang Long \\ Tan Owee Kowang \\ Faculty of Management, Universiti Teknologi Malaysia \\ Email: slchoi@utm.my,oktan@utm.my
}

\section{Doi:10.5901/mjss.2015.v6n1p377}

\begin{abstract}
It is utmost important for manufacturers to improve competitiveness and leaders' characteristic is vital to make this goal attainable. Leaders' emotional intelligence (EI) is crucial in this aspects. One of it is to boost employees' commitment and improve productivity of employees. This paper looks into the relationship between leader's El and organizational commitment (OC) of their subordinates. Two types of organization which is a multi- national company and a locally owned company are chosen to conduct this comparative study. The correlational analysis was conducted on these 2 companies and indicated a statistically significant and a positive relationship between the 4 dimensions of El and OC.
\end{abstract}

Keywords: Emotional intelligence; leadership; organization commitment; manufacturing; affective.

\section{Introduction}

A key function of Emotional Intelligence (EI) is to facilitate collective understanding and build positive human relations in organizations, by equipping managers with the requisite skill set to enhance staff performance and commitment (Jewell, 2007).

El is increasingly being used by researchers and organizations to assess people behavior, attitudes, interpersonal skills and to gauge the organizational commitment of managers and lower line staff. As an indicator, data on Emotional Intelligence is now being employed manpower planning, job profiling as well as recruitment and selection processes (Jewell, 2007).

Organizational commitment precipitates employee loyalty, wherein individual workers demonstrate their dedication to an organization irrespective of its successes and failures (Meyer \& Allen, 1997). Often times this is gauged through behaviors such as regular attendance at work - putting in a full day or long hours; protecting company assets, voluntarily taking on new roles outside of one's job description and sharing company goals and values. Commitment is often taken as an indication of an employees' desire to remain with an organization (Long \& Perumal, 2014). Organizations generally view having committed employees as an advantage.

Law et al (2004) declared that leaders with higher El typically performed better. Therefore, a positive leadersubordinate relationship in a more conducive working environment would lead to a higher organization commitment by the subordinate. Rayton (2006) suggested that there is a strong possibility that another variable influenced job satisfaction and organization commitment. It is posited in current research that the missing variable is El. Thus this research will contribute to this body of knowledge if a relationship does exist between leaders El and OC of subordinates.

\subsection{Rationale of Study}

Emotional Intelligence (EI) has been reviewed and studied extensively, but predominantly in the United States, Europe and Australia (Densten, 1999). It is arguably viewed as a germane concept to deconstruct given the influx of MultiNational Companies shifting from West to East, yet very few studies have been conducted in Asia. With the era of globalization and the fact that many Multi-National Companies (MNC) have opted to move their production plants into South East Asia, this study seeks to examine the adoption of El models in Malaysia, a hub for transnational trade and activity but also a more conservative region than its Western counterparts. 


\section{Literature Review}

\subsection{Theories on Emotional Intelligence}

There exist numerous theories on Emotional Intelligence, but for the most part utilized in research are the theories of BarOn, Goleman, and Salovey and Mayer (Engstrom, 2005). Emotional Intelligence models by and large encompass 2 categories, namely ability-based and mixed models. The ability based model describes Emotional Intelligence as a complete form of mental ability or pure intelligence. On the contrary, the mixed models describe Emotional Intelligence as a combination of mental ability having elements of personality traits, skills and motivation. Both Goleman (1995) and BarOn's (1997) research generated the mixed models of Emotional Intelligence.

Goleman (2001) defined El as the capacity for recognizing our own feelings and those of others, for motivating ourselves, and for managing emotions well in ourselves and in our relationships. He also introduced the 4 concept model in this book. The model is: Self awareness, Self-management, social awareness and Relationship Management. Self awareness being one's competency to study one's emotions and identify its impact while using instinct to guide their decisions. Self management is the controlling of one's emotions, urges, and adjusting to changing circumstances. Social awareness encompasses the competency to comprehend sense and respond to the emotions of others while understanding the concept of interaction of people. Lastly, relationship management, which is the competency to motivate, develop and influence others in managing conflicts.

\subsection{Theories on Organizational Commitment}

In the recent years, Organizational Commitment has been an area of interest among researchers be-cause of its relationship with $\mathrm{El}$ and the principle that it ultimately boil down to organizational success and efficiency (Meyer and Allen, 1997). There are a variety of definitions on Organizational Commitment that can be found in literature. Porter et al., (1974) described organizational commitment as being a composition of three major components namely; a strong belief in and acceptance of the or-ganization's goals, a willingness to exert considera-ble effort on behalf of the organization, and a defi-nite desire to maintain organizational membership. Buchanan (1974) defined commitment as being a bond between an individual and the organization, through his own definition of commitment. In 1997, Meyer and Allen defined $\mathrm{OC}$ to include that of a committed employee is the one who stays with the organization through thick and thin, attends work regularly, puts in a full day (and maybe more), pro-tects company assets, shares company goals and so on. Meyer and Allen (1991) had defined OC to comprise of 3 types of commitment ;-

a) Affective Commitment (AC)

It is identified as the emotional involvement, af-finity, and association that an employee has with its organization and its goals (Meyer \& Allen, 1993; Mowday et al., 1998). Meyer and Allen (1997) ex-panded on this definition to say that employees maintained association with the organization on their own accord and that was their way of portray-ing loyalty to the organization.

b) Continuance Commitment (CC)

Is when an employee remains in an organization as they feel that they need to, usually due to finan-cial reasons, and they associate leaving with a loss that is associated with cost. Meyer and Allen (1997) extended on this to say that employees who share such a commitment with their employers found it that much harder to leave the organization.

c) Normative Commitment (NC)

Is when an employee feels for some reason an obligation to stay with the organization. Meyer and Allen (1991), defined it as a feeling of obligation, where else Weiner (1982), defines it as a general-ized value of loyalty and duty.

\subsection{The Relationship between Emotional Intelligence and Organizational Commitment}

One of the earliest works done on this subject matter was by Abraham (1999) stressed that Emotional Intelligence prevents the individual from holding the organizational responsible for every frustration and conflict on the job and, thus, prevents the erosion of commitment that results from indiscriminate fault finding. In this study he found that $15 \%$ of the differences in OC were explained exclusively by El. Momeni (2008) in her study of Public Personnel in Iran showed that Manager's Emotional Intelligence has a positive association with their subordinates $\mathrm{OC}$. The results of the analysis of the relationship between the dimensions of EI and OC showed a positive correlation between the dimensions of both 
principles. The regression analysis that was conducted by Momeni indicated that $55 \%$ of the OC of employees is caused by the El of Managers.

Nikolaou and Tsaousis (2002), in their studies found a positive correlation between 4 dimension of El and employee OC. Namely, Perception and Appraisal (0.81), Control of emotions (0.94), Use of emotions (0.95) and Understanding and reasoning (0.90), these results were alpha reading measurements, on a population sample of 212 healthcare professionals.

Carmelli (2003), studied the relationship between El and some OC factors such as behavior, performance and work attitudes, the results of this study showed a substantially positive relationship between El and AC (.24) and (.32) for the relationship between El and performance. The underlying results were that the various constructs of OC associated differently to factors such as job performance and work behavior.

Humphreys et al., (2005), found correlation between El and AC, a construct of OC. Adeyemo (2007), Nigeria, also discovered a positive correlation via hierarchical regression analysis between $\mathrm{OC}$ and El. Ultimately confirming that EI has a major influence on the constructs of OC. The research done by Abraham (1999) and Wong and Law (2002) which confirmed the positive relationship between El and OC was supported by Perez et al (2005) in their study involving 167 adult professionals. Prati (2004), not only proved a positive relationship existed between El and OC but also added emotional intelligence (change in $\mathrm{R}^{2}=0.03, \mathrm{p}<0.01$ ) is a predictor of organizational commitment.

Despite all the positive correlations between El and OC, there were some studies that cast a shadow of doubt between the relationships. Stewart (2008) in his study in the food industry stresses that there is no relationship between the total El scores and OC for managers. However, he did mention that there was a possibility that because the relationship between customers and employees were brief therefore, the need for El skills were minimum. Another point that was made in the defense of his study was that most of the managers in his study did not see a career path in their current job. Humphreys et al (2003) concluded in his studies that, follower El was positively correlated to OC, thus his deduction of the relationship was that subordinate El played a greater role in enhancing the subordinate OC than the managers El.

\section{Method}

This study employed quantitative approach. This is a standardized approach that permit the study to be replicated in different areas or over time with the production of comparable findings. The population was basically white collared workers in both the locally owned company (LOC) and a multi-national company (MNC). The sampling frame was the leaders of the company from Executives to Managers and above, and their immediate subordinates. They were from Marketing, Research and Development, Finance, Customer Services, IT and Human Resources from all their subsidiaries across Malaysia. 56 Executives, Managers and above; 70 Clerical staff represented the MNC's 126 total sampling frame that sent back their questionnaires from the 150 questionnaires sent out. On the LOC, 55 executives, managers and above; 68 clerical staff represented the 123 of the total of 150 .

The 4 dimensions of El which are Self Emotion Appraisal (SEA), Other Emotion Appraisal (OEA), Use of Emotion (UOE), Regulation of Emotion (ROE) of leaders' and the respondent organization commitment are measured using questionnaires.

\section{Result}

Table 1 showed the result of correlational analysis on two types of organizations (Multinational and Locally Owned Companies). All dimensions of El dimensions are significantly correlated with $\mathrm{OC}$. The $\mathrm{R}^{2}$ and the Adjusted $\mathrm{R}^{2}$ value for both these organizations are also reported as shown in the table. The Adjusted $\mathrm{R}^{2}$ explains that the data is $41 \%$ and $39 \%$ of the total OC of subordinates is affected by 4 dimensions of Emotional Intelligence, for the Multi National Company and the Locally Owned Company. 
Table 1. Correlational Analysis

\begin{tabular}{|c|c|c|}
\hline \multicolumn{3}{|c|}{ Participants of the Multi-National Company } \\
\hline OC & El Dimensions & Pearson Correlation \\
\hline Total OC & SEA & ${ }^{\star \star} 0.564$ \\
\hline Total OC & OEA & ${ }^{* \star} 0.576$ \\
\hline Total OC & ROE & $\star \star 0.592$ \\
\hline Total OC & UOE & ${ }^{\star *} 0.402$ \\
\hline \multicolumn{3}{|c|}{${ }^{*} p<.05$ (2 tailed), ${ }^{* \star} p<.01$ (2 tailed) $R^{2}=0.446$ Adjusted $R^{2}=0.407$} \\
\hline \multicolumn{3}{|c|}{ Participants of the Locally Owned Company } \\
\hline $\mathrm{OC}$ & El Dimensions & Pearson Correlation \\
\hline Total OC & SEA & $\star \star \star 0.552$ \\
\hline Total OC & OEA & $\star \star 0.563$ \\
\hline Total OC & ROE & $\star \star 0.581$ \\
\hline Total OC & UOE & $\star \star 0.396$ \\
\hline
\end{tabular}

Field independent learners readily separate key details from a complex or confusing background, while their field dependent peers have trouble doing this. For instance, field-independent learners tend to be analytical people; in language learning they tend to focus on form and accuracy; they look out for rules and patterns; they like to plan what they have to say or write; and they like abstract, impersonal, factual material. On the other hand, field-dependent learners tend to be synthetic people; in language learning they tend to focus on meaning and fluency; they collect examples of language use rather than form rules; they like to produce an oral or written text in a straightforward way, and later correct it if necessary; and they like material which is of a more concrete, human, social or artistic nature.

\section{Discussion and Conclusion}

The correlational analysis conducted on these 2 companies indicated a statistically significant and a positive relationship between the 4 Dimensions of El and total OC. The results obtained from the Re-gression Model between the 4 Dimensions of El as the Independent Variable and the total OC support the research done by Abraham (1999) and Momeni (2008). From the results, we can conclude that the 4 Dimensions of leaders El does have a statistically significant positive relationship with the total con-structs of subordinates OC. From the results of this study, it supports the findings of Prati (2004) in which it was said that Emotional Intelligence is a predictor of the OC. However, the results also showed that there was no significant difference be-tween a MNC and a locally owned company. McEnrue \& Groves (2006) suggested that the Human Resource Practitioners should concentrate on developing the attributes in their leaders such as understanding, assessing and the development of Emotional Intelligence.

\section{Acknowledgement}

Authors wish to acknowledge the Malaysian Minis-try of Higher Education and Universiti Teknologi Malaysia under the Research Grant (Vot. 4F349) for supporting and sponsoring this publication.

\section{References}

Abraham, R. 1999. Emotional intelligence in organizations: A conceptualization. Genetic, Social and General Psychology Monographs, 125(2), 209-224.

Adeyemo, D. 2007. Emotional intelligence and the relationship between job satisfaction and organizational commitment of employee in public parastatals in Oyo State, Nigeria. Pakistan Journal of Social Sciences, 4(2), 324-330.

Bar-On, R. 1997. Bar-On Emotional quotient Inventory (EQ-i) Technical Manual. Toronto, Canada : Multi-Health Systems, Inc.

Buchanan, B., II. 1974. Building organizational commitment: The socialization of managers in work organizations. Administrative Science Quarterly, 1974. 19, 533-546.

Carmeli, A. 2003. The Relationship between El and work attitudes, behavior and outcomes. Journal of Managerial Psychology, 18(8), 788-793.

Densten, I. 1999. Senior Australian Law Enforcement Leadership Under Examination, Policing: An International Journal of Policing Strategies \& Management. 22(1), 47-57. 
Engstrom, M. 2005. A study of emotional intelligence as it relates to organizational outcomes beyond what is contributed by personality (Doctoral Dissertation, Loyola University Chicago, United States - Illinois). ProQuest Psychology Journals database. (Publication No. AAT 3191340).

Goleman, D. 1995. Emotional Intelligence: Why it can matter more than IQ. New York : Bantam Books.

Goleman, D. 2001. An El based theory of performance. In C.

Humphreys, J., Brunsen, B., \& Davies, D. 2005. Emotional structure and commitment: Implications for health care management. Journal of Health Organization and Management, 19(2), 120-129.

Humphreys, J., Weyant, L., \& Sprague, R. 2003. Organizational commitment: The roles of emotional and practical intellect with the leader/follower dyad. Journal of Business \& Management, 9(2), 189.

Jewell, G. B. 2007. The Relationship between emotional intelligence and organizational commitment in frontline service providers. Unpublished manuscript.

Law, K. , Wong, C., \& Song, L. 2004. The construct and crite rion validity of emotional intelligence and its potential utility for management studies. Journal of Applied Psychology, $89: 483-496$.

Long, C.S \& Perumal , P (2014). Examining the Impact of Human Resource Management Practices on Employees' Turnover Intention. International Journal of Business and Society. 15(1), 111-126.

McEnrue, M., \& Groves, K. 2006. Choosing among tests of emotional intelligence: What is the evidence? Human Resource Development Quarterly, 17(1), 9-42.

Meyer, J. , \& Allen, N. 1991. A three component conceptualization of organizational commitment. Human Resource Management Review, 1, 61-89.

Meyer, J., Allen, N., \& Smith, C. 1993. Commitment to organizations and occupations: Extension and test of a three-component conceptualization. Journal of Applied Psychology, 78(4), 538-551.

Meyer, J., \& Allen, N. 1997. Commitment in the workplace: Theory, research, and application. Thousand Oaks, CA: Sage publications.

Momeni, N. 2008, The Revelation Between Manager's Emotional Intelligence and the Organizational Climate they create. Public Personnel Management, 38(2), 11-18.

Mowday, R. 1998. Reflections on the study and relevance of organizational commitment. Human Resource Management Review, 8(4) , 387-401.

Nikolaou, I. Tsaousis, I. 2002. Emotional Intelligence in the workplace: Exploring its effects on occupational stress and organizational commitment. The International Journal of Organizational Analysis, 10(4), 327-342.

Perez, J., Petrides, K., \& Furnham, A. 2005. Measuring trait emotional intelligence. In R. Schulze, \& R. Roberts (Eds.), Emotional Intelligence : An international handbook. Cambridge, MA: Hogrefe and Huber, 181-201.

Porter, L., Steers, R., Mowday, R., \& Boulian, P. 1974) Organizational commitment, job satisfaction, and turnover among psychiatric technicians. Journal of Applied Psychology, 59(4), 603-609.

Prati, L. 2004. Emotional Intelligence as a facilitator of emotional labour process (PhD dissertation, The Florida State University, United States of America). Publication No. AAT 3160677.

Rayton, B. A. 2006. Examining the interconnection of job satisfaction and organizational commitment: An application of the bivariate probit model. International Journal of Human Resource Management, 17(1) :139-154.

Rosete, D., \& Ciarrochi, J., 2005 ;"Emotional Intelligence and its relationship to workplace performance outcomes of leadership effectiveness". Leadership \& Organization Development Journal, 26(5), 388-399.

Stewart, G. 2008. The relationship of emotional intelligence to job satisfaction and organization commitment (Doctoral dissertation, Regent University, Virginia, United States of America. Publication No. AAT 3319386).

Weiner, Y. 1982. Commitment in Organization: A Normative View. Academy of Management Review, 7, 418-428.

Wong, C., Law, K. 2002. The effects of leader and follower emotional intelligence on performance and attitude: An exploratory study. The Leadership Quarterly, 13(3), 243-274. 